\title{
Método e inventio: diálogo entre Literatura e História na obra Todos os Nomes de José Saramago
}

\author{
Method and inventio: dialogues between literature and history in \\ José Saramago's All The Names book \\ Método e inventio: diálogo entre Literatura e Historia en la obra \\ Todos los nombres de José Saramago
}

\section{Euclides Antunes de Medeiros ${ }^{1} 1$}

Olivia Macedo Miranda Cormineiro ${ }^{1} 1$

1 Universidade Federal do Tocantins, Araguaína, Tocantins, Brasil.

$\diamond$

\begin{abstract}
RESUMO
Escrever sobre uma obra literária é um esforço complexo, pois envolve interpretar os sentidos de uma narrativa criativa e criadora. Escrever sobre as potencialidades de que a história possa vir a aprender sobre metodologia com o exercício literário é ainda mais complexo, pois requer um esforço de liberação de alguns padrões estabelecidos acerca dos lugares da história e da literatura, enquanto campos distintos. Nesse sentido, esse artigo problematiza, a partir da obra literária Todos os Nomes de José Saramago, a possibilidade de a literatura poder auxiliar a história não apenas na construção da verossimilhança, mas, sobretudo, como ela pode apontar, a partir de sua própria escrituração inventiva, caminhos para a construção de procedimentos de investigação e pesquisa.
\end{abstract}

Palavras-chave: Método. Inventio. Literatura. História. José Saramago.

\begin{abstract}
Writing about a literary work is a complex effort because it involves interpreting the meanings of a creative narrative. Writing about the potentialities that history can learn about methodology from literary practice is even more complex, once it requires an effort to release some established standards about the roles of history and literature as distinct fields. In this way, this article discusses, from the literary work All the Names of José Saramago, the possibility that literature offers to the history field not only in the building of verisimilitude but, overall, how it can point out ways for the investigation buildings and research procedures, from its own inventive writing.
\end{abstract}

Keywords: Method. Inventio. Literature. History. José Saramago.

\section{RESUMEN}

Escribir sobre una obra literaria es un esfuerzo complejo, pues implica interpretar los sentidos de una narrativa creativa y creadora. Escribir sobre las potencialidades de que la historia pueda venir a aprender sobre metodología con el ejercicio literario es aún más complejo, pues requiere un esfuerzo de liberación de algunos patrones establecidos acerca de los lugares de la historia y de la literatura, como campos distintos. En ese sentido, ese artículo problematiza, a partir de la obra literaria Todos los Nombres de José Saramago, la posibilidad de que la literatura pueda auxiliar la historia no sólo en la construcción de la verosimilitud, pero sobre todo, como ella puede apuntar, a partir de su propia escrituración inventiva, caminos para la construcción de procedimientos de investigación e investigación.

Palabras clave: Método. Inventio. Literatura. Historia. José Saramago. 


\section{Introdução}

Um dos autores que privilegia em sua obra as relações instáveis e fundamentais entre história, literatura e pensamento social é o literato português José Saramago. Nascido na província de Ribatejo em novembro de 1922, filho e neto de camponeses, a vida de Saramago transcorreu quase que inteiramente em Lisboa, embora tenha mantido laços estreitos e profundos com sua aldeia de nascimento. Em razão de dificuldades econômicas cursou apenas até o secundário, tendo logo depois começado a trabalhar; inicialmente foi serralheiro mecânico, mas exerceu trabalhos como desenhista, agente de saúde e da previdência social, editor e jornalista.

Sua carreira literária começou aos 25 anos, em 1947, quando publicou o romance Terra do Pecado, porém só voltou a publicar em 1966, quando surgiu a obra Poemas Possíveis. Envolvendo-se cada vez mais com a escrita ficcional, Saramago passou a viver exclusivamente de seu trabalho literário a partir de 1976. Em 1998 ele foi agraciado com o Prêmio Nobel de Literatura pelo conjunto de sua obra. Depois de produzir uma vasta obra literária ${ }^{1}$, Saramago faleceu a 18 de junho de 2010.

Assim, ao menos desde 1976, seu trabalho com as palavras floresceu com vigor impressionante, seus enredos se constituíam de tramas que imbricava personagens reais e personagens inventadas a lances históricos que irrompiam de suas páginas como momentos invioláveis de metaficção, pois segundo o próprio Saramago a história, em seu discurso, abandonava amplas "zonas de obscuridade", lacunas culturais, sociais e subjetivas "por onde pode e deve entrar o romancista" (1989, p. 9).

A relação entre a ficção e a história é uma das principais características da literatura do português, mas ele não concebe essa relação como uma justaposição de campos ou dimensões de escrita, ao contrário. O que Saramago faz em suas obras é acalentar uma estrutura de linguagem que destrói os limites desses campos, como esclarece Maria Helena Sansão Fontes (2010, p. 75):

Saramago tem marcadamente o histórico e o ficcional fundindo-se em vários de seus textos, como Memorial do Convento; A jangada de pedra; História do Cerco de Lisboa e $O$ ano da morte de Ricardo Reis, entre outras narrativas. Nessa medida, ele se incumbe da História, ficcionalizando-a [...]. A narrativa de Saramago jamais busca o passado para celebrá-lo ou para um simples conhecimento da história. É através da subjetivação,

\footnotetext{
1 Dentre a vasta obra de José Saramago destacamos os seguintes romances; Terra do Pecado (1947); Manual de Pintura e Caligrafia (1977); Levantado do Chão (1980); Memorial do Convento (1982); O Ano da Morte de Ricardo Reis (1984); A Jangada de Pedra (1986); História do Cerco de Lisboa (1989); O Evangelho Segundo Jesus Cristo (1991); Ensaio sobre a Cegueira (1995); e Todos os Nomes (1997).
}

da autorreflexividade e da transcendência da história que seus narradores indagam o passado. Sendo assim, o questionamento, a subversão do passado histórico, a rasura de acontecimentos, a intencional desconstrução e dessacralização de fatos históricos oficiais fazem parte dos seus romances. É de interrogação, portanto, que se constitui a obra de Saramago no que diz respeito à história.

Em seus romances o ponto de intersecção e ao mesmo tempo de transgressão é o tênue equilíbrio entre a metaficção e a meta-história. Saramago não deseja estabelecer fronteiras; o que deseja é instituir novas formas de inscrever o mundo, formas estas capazes de atribuir sentido àquelas "zonas de obscuridade" ao interrogar a história incessantemente. Obviamente as discussões que envolvem literatura e história são antigas e complexas, desde a antiguidade proliferam discursos sobre esse tema, como provoca o historiador Carlo Ginzburg (2007, p. 14):

Os historiadores, escreveu Aristóteles (Poética, 51b), falam do que foi (do verdadeiro), os poetas, daquilo que poderia ter sido (do possível). Mas, naturalmente, o verdadeiro é um ponto de chegada, não um ponto de partida. Os historiadores (e, de outra maneira, também os poetas) têm como ofício alguma coisa que é parte da vida de todos: destrinchar o entrelaçamento de verdadeiro, falso e fictício que é a trama do nosso estar no mundo.

Não é improvável que José Saramago tenha decifrado o segredo dessa esfinge ao conceber o seu ofício a partir do que há em comuns entre poetas e historiadores, porém, diferentemente dos últimos, ele não considerou o verdadeiro como o ponto de chegada, mas como algo que merecia ser reinventado. Reinventar a história, reinventar o nosso "estar no mundo", tinha um sentido profundo para Saramago, algo que ele esclarece ao fazer referência a trecho de um poema de Álvaro de Campos², citado no romance Jangada de Pedra (1986):
Ah, quem escreverá a história do que poderia ter sido? Será essa, se alguém a escrever, A verdadeira história da humanidade (CAMPOS apud SARAMAGO,1989, p. 13).

A "história" que Saramago escreveu, a verdadeira história do "estar no mundo" da humanidade era aquela atribuída por Ginzburg aos poetas: "a história do que poderia ter sido". A verdadeira história da humanidade para o mestre português não era aquela dos fatos como narrados pela historiografia, mas aquela construída nos desvios tomados pela imaginação que, a despeito de reis

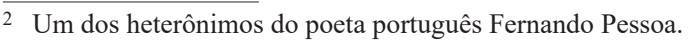


e rainhas reais que circulam em seus romances, tinha na ficção a oportunidade de registrar a existência das pessoas comuns, pois:

[...] já que não podemos falar-lhes das vidas, por tantas serem, ao menos deixemos os nomes escritos, é essa a nossa obrigação, só para isso escrevemos, torná-los imortais, pois aí ficam, se de nós depende (SARAMAGO, 1997, p. 233).

Presente no romance Memorial do Convento, esse trecho é enunciado pelo narrador como se para combater o esquecimento que vitimava os personagens encarregados de mover a imensa pedra que seria colocada no pórtico da Igreja. A solução na escrita imaginativa de Saramago era o registro: deixaria todos os nomes escritos no memorial do convento, pois importava reconhecer a relevância dos "pequenos personagens"; talvez aí esteja um dos seus legados aos historiadores: ser capaz de expressar na sua escrita a autoconsciência do processo de (re) construção da história seja ela fictícia ou não.

Contudo, a contribuição de Saramago para historiografia que pretendemos discutir nesse texto não se refere à sua proposição de que é preciso estar atento a esse processo de autorreflexão sobre a arte de (re)construir e/ ou criar narrativas. O que propomos é explorar em um de seus romances, Todos os nomes (1997), a capacidade de sua arte literária de fazer suscitar questões metodológicas e de procedimentos históricos no interior da trama da própria obra.

\section{Todos os nomes, todas as descobertas}

Publicado originalmente em 1997, Todos os nomes, do escritor português José Saramago, é um romance extraordinariamente incomum. Ambientando em uma cidade imaginária, as cenas centrais acontecem em uma repartição pública cuja função era arquivar os registros de nascimentos, casamentos, divórcios e falecimentos: Conservatória Geral do Registro Civil ${ }^{3}$. Nela estão dois arquivos: os dos vivos, onde atuam os empregados e os dos mortos onde se encontram "os papéis" dos que já faleceram. $\mathrm{O}$ arquivo dos vivos é dinâmico, pois ali estão anotados os sinais dos homens e mulheres que se movem pela vida; o arquivo dos mortos seria, segundo o chefe da Conservatória um peso duas vezes "morto, dado que é raríssimo preocupar-se alguém com eles, só de longe em longe se apresenta aqui algum pesquisador de miudezas históricas de escassa relevância" (SARAMAGO, 2014, p. 14). Sem dúvida o arquivo dos mortos era o espaço dos esquecimentos, pois ali:

\footnotetext{
3 Nome atribuído em Portugal ao Cartório de Registro de Pessoas Naturais.
}

[...] prosperou o abandono, multiplicou-se a incerteza, a ponto de um dia se ter perdido nas labirínticas catacumbas do arquivo dos mortos um investigador que, meses depois da absurda proposta, se apresentou na Conservatória Geral para efectuar umas pesquisas heráldicas que lhe haviam sido encomendadas. Foi descoberto, quase por milagre, ao cabo de uma semana, faminto, sedento, exausto, delirante [...] O chefe da Conservatória Geral [desde então] baixou uma ordem de serviço que determinava [...] a obrigatoriedade do fio de Ariadne para quem tivesse que ir ao arquivo dos mortos (SARAMAGO, 2014, p. 15).

À exceção dos historiadores de miudezas, o arquivo dos mortos, nos informa o narrador, não era de interesse dos vivos, ali, onde "reina[va] a escuridão" (SARAMAGO, 2014, p.14), o risco de que alguém se perdesse nos labirintos só podia ser mitigada com o recurso do fio de Ariadne ${ }^{4}$. A intenção do conservador geral ao instituir esse mecanismo foi criar algum padrão de segurança, mas o narrador de Todos os nomes passeia distraidamente por questões transcendentes: os vivos e os mortos na Conservatória eram separados e hierarquizados em função de sua importância para o presente. No caso, quanto mais um verbete - como eram nomeadas as fichas nas quais se anotava nascimentos, casamentos, divórcios e falecimentos - de registro dos vivos se aproximasse "do fim da prateleira, [mais seria], em todos os sentidos, o princípio da queda": quando estaria na borda extrema do vazio, encerrando a "duração aconselhável duma existência humana" (SARAMAGO, 2014, p. 16).

Um jogo de linguagem constitui os arquivos que já não se encontram entre os vivos como um tabu, sintomático da inquietação primordial de Saramago sobre o lugar da humanidade na narrativa do mundo. Porém, na trama de Todos os nomes a ideia de humanidade se distância dos objetivos práticos da conservatória. Talvez esta seja uma das primeiras perguntas que esse romance suscita ao historiador: $\mathrm{O}$ que estamos buscando da história da humanidade?

De fato, ao menos no início da obra o que fazia a conservatória existir era a constante mobilização dos vivos, surgindo aqui a personagem principal do romance: Sr. José. Sr. José é um auxiliar de escrita, rigoroso com o cumprimento de suas atividades profissionais, e vive tediosamente em uma pequena casa anexa à repartição. A rotina do Sr. José apenas é abalada por um hábito que possui: colecionar informações colhidas em jornais

\footnotetext{
4 Na mitologia grega Ariadne, filha do soberano de Creta, Minos, e de Pasífae, enamora-se de Teseu quando este se dispõe a adentrar a estrutura labiríntica que fora criada no Palácio de Cnossos, para enfrentar o Minotauro que ali habitava. Mas Ariadne, apaixonada, oferece à Teseu uma espada para ajudá-lo na luta contra o monstro, e o fio de Ariadne, que o guiaria de volta ao exterior.
} 
e revistas sobre a vida de celebridades, autoridades e famosos nacionais. Esse auxiliar de escrita, como todo colecionador, faz suas coleções em função de "algo que poderíamos chamar angústia metafísica, talvez por não conseguirem suportar a ideia de caos como regedor único do universo, por isso, com suas fracas forças e sem ajuda divina, vão tentando colocar por ordem no mundo [...]" (SARAMAGO, 2014, p. 23).

Ao menos duas questões podem ser levantadas aqui. Primeiro, colecionar fatos, colocar ordem no mundo, é uma atitude humana e não divina, pois são os homens que atuam na construção dos sentidos do que é dado a conhecer. Segundo, essas complexas práticas que se caracterizam como um exercício de ordenamento do caos é uma atividade humana, mas também é uma utopia do historiador. A angústia metafísica que rege o impulso de colecionador do Sr. José representa não apenas seus hábitos pessoais, mas figura o estrato primário do interesse historiográfico, nas palavras do historiador Edward Hallet Carr (1985, p. 77):

verdadeiro historiador, confrontado com [uma] [no original "esta"] lista de causa de sua própria compilação, sentiria uma compulsão profissional para colocá-la em ordem, para estabelecer alguma hierarquia de causas que fixaria suas relações recíprocas.

O que sutilmente enuncia-se no início do romance, são as encruzilhadas do mundo da pesquisa, desde os impulsos do pesquisador até a busca por colocar em ordem o caos por meio do ordenamento do material de pesquisa, mas não somente isso: estão em jogo também as escolhas do pesquisador e o problema constante da obra de Saramago: quem e como inscrever narrativamente o "estar no mundo". No que concerne à escolha de quem inscrever, Sr. José tem claras preferências: eram as celebridades e famosos que lhe excitavam a curiosidade. Entretanto, o como inscrever acarreta mudanças profundas na identidade desse auxiliar de escrita.

Vejamos, as coleções de celebridades de Sr. José ocupavam-lhe as noites, quando se dedicava a recortar as notícias e histórias de seus escolhidos, porém, em certa ocasião, atualizando as informações de um bispo, "teve a iluminação que iria transformar sua vida" (SARAMAGO, 2014, p. 25).

É bem possível que a consciência de estar perto da Conservatória Geral do outro lado da grossa parede, [...] a escuridão abissal que reinava no fundo da nave, a solidão, o silêncio, é possível que tudo isto, num instante, $[\ldots]$ o tivesse feito perceber que algo de fundamental estava a faltar em suas coleções, isto é, a origem, a raiz, a procedência, por outras palavras, o simples registro de nascimento das pessoas famosas cujas notícias de vida pública se dedicara a compilar.
Não sabia, por exemplo, como se chamavam os pais, nem quem tinham sido os padrinhos [...nem onde havia nascidos $[\ldots]$ e, quanto à data de nascimento, se era certo que por alguma causalidade constava de recorte um destes, só o registro oficial da Conservatória, evidentemente, faria verdadeira fé, nunca uma informação avulsa colhida da imprensa [...] (SARAMAGO, 2014, p.25).

Aqui Saramago trabalha com uma figuração da linguagem que remete o leitor ao contraste entre iluminação e escuridão ou, mais especificamente, entre o despertar de uma clareza sobre por onde começar uma pesquisa e os passos incertos, vacilantes, de um pesquisador que se vê diante de uma descoberta metodológica. Nesse primeiro momento, Sr. José era impulsionado pela ideia de aprofundar seus conhecimentos sobre os alvos de suas coleções, pois percebe que seu material carecia ser autenticado e, talvez, a proximidade com a Conservatória tenha lhe fornecido uma das chaves de sua investigação: seria necessário que ele se lançasse na escuridão, na solidão e no silêncio dos arquivos, surgindo no horizonte o que ele julgava ser seu como. Desde aquele momento o auxiliar de escrita resolveu transgredir uma das regras expressas da Conservatória Geral: começou a frequentar os arquivos durante a noite, fora do expediente, para extrair o material que lhe faltava sobre os famosos:

a excitação com que o Sr. José abriu pela primeira vez a porta proibida, o calafrio que o fez deter-se à entrada, como se tivesse posto o pé no limiar duma câmara onde se encontrasse sepultado um deus cujo poder, ao contrário do que é tradicional, não lhe adviesse da ressurreição, mas de tê-la recusado. Só os deuses mortos são deuses sempre" (SARAMAGO, 1997, p. 26).

Todas as sensações experimentadas pelo Sr. José podem ser estendidas aos pesquisadores iniciantes, mas não somente a estes, podem também ser ampliadas para aqueles historiadores que nutrem uma paixão pelo seu ofício e pelo processo de descobrir. Estava a personagem Sr. José em um "limiar" enunciado metaforicamente como uma porta que dividia dois universos: o da personagem insignificante, covarde, o José cujo sobrenome ninguém se importava e um mundo da personagem futura, a personagem que virá a ser, corajosa, impetuosa, desdenhosa da própria sorte à medida que se construiria como alguém capaz de reinventar alguma humanidade nos homens. A porta, pois, é enunciada como um espaçotempo crítico e transpô-la, transgredi-la, pressupõe um momento de crise que anuncia uma ruptura.

A "câmara", o labirinto que era a Conservatória Geral do Registro Civil, antes de transgredida, é, de um lado, a alegoria de uma sociedade hierarquizada pela 
tradição tendo esta já sido personificada no chefe da Conservatória e seu respectivo título, o Sr. Conservador, e figurada por meio das rígidas relações hierárquicas impostas pela sua presença e pelo conhecimento que detinha, pois, conforme enuncia o narrador do romance, "[...] O cérebro de um conservador é como um duplicado da Conservatória"(2014, p. 62). E o era por saber "de cor todos os nomes que existem e que existiram, todos os nomes e todos os apelidos" (SARAMAGO, 2014, p. 62).

De outro lado, o fato de que apenas ao conservador geral era permitido conhecer todos os nomes dos mortos e dos vivos figurava a autoridade do arquivo não apenas de tudo conservar, mas também de, hipoteticamente, saber tudo o que deveria ser sabido. No entanto, para transgredir essa legitimidade, Saramago retira de Todos os nomes todos os nomes próprios, à exceção do $\mathrm{Sr}$. José, nomeando os personagens como "senhora do rés do chão", "senhor conservador" "subchefe", "pastor de ovelhas", dentre outros, ironicamente redimensionando os discursos de autoridade no romance.

Quanto ao Sr. José, ao transpor aquele limiar, ele transformou em uma prática recorrente a visita ao arquivo da conservatória geral para retirar os verbetes e transcrevê-los. Entretanto, mais uma reviravolta é urdida, por José Saramago, na vida do Sr. José, enquanto coletava verbetes de alguns famosos:

Tão depressa quanto lho permitiram os dedos aflitos, pôs-se a abrir e fechar gavetas, a procurar nas diferentes letras do alfabeto os verbetes de que precisava, equivocou-se uma vez e outra, até que finalmente conseguiu reunir os primeiros cinco famosos da segunda categoria. [...] Julgava ele que eram cinco, [mas] com os arrancos [de uma] tosse tinha acabado por deixá-los cair, e não eram cinco, eram seis, espalhados ali no chão [...]. Quando conseguiu recuperar o fôlego, baixou-se para apanhar os verbetes, um, dois, três, quatro, cinco, não havia dúvida, seis, à medida que os recolhia ia lendo os nomes que lá estavam, famosos todos, menos um (SARAMAGO, 2014, p. 37).

Entre o momento em que descobre o sexto verbete e a mudança de rumo nos interesses de pesquisa, Sr. José inquieta-se com o acaso daquela descoberta insignificante. Era a ficha de registro civil de

[...] uma mulher de trinta e seis anos, nascida naquela mesma cidade, e del[a] constam dois averbamentos, um de casamento, outro de divórcio, Como este verbete haverá centenas no ficheiro, senão milhares, portanto não se compreende por que estaria o Sr. José a olhar para ele com uma expressão tão estranha, que à primeira vista parece atenta, mas que é também vaga e inquieta, possivelmente é este o modo de olhar de quem, aos poucos, sem desejo nem recusa, se vai desprendendo de algo e ainda não vê aonde poderá deitar a mão para tornar a segurar-se (SARAMAGO, 2014, p. 38).

O que havia de especial naquele verbete para chamar a atenção do Sr. José? Era uma mulher comum, dentre tantas, e não apresentava qualquer marca distintiva. Mesmo depois que decidirá perseguir a história da "mulher desconhecida", "alguns dias depois, o auxiliar de escrita não saberia dizer o que o levou a tal" (SARAMAGO, 2014, p. 42). Talvez, uma resposta prematura possa ser encontrada na própria intencionalidade do autor de Todos os nomes (2014). Assim como em Memorial do Convento (2013), onde transforma D. João V e Dona Maria Ana em personagens secundários da obra elegendo Blimunda e Baltasar, pessoas comuns, como protagonistas, em Todos os nomes a centralidade é transferida dos verbetes de famosos para o de uma "mulher desconhecida" em função do desejo do próprio autor de visibilizar em suas obras a vida das pessoas esquecidas e quase apagadas da história.

Certamente, essa é uma questão relativa às convicções políticas de José Saramago. Marxista convicto, o mestre português construiu sua trajetória literária calcada em uma estrutura de sentidos que coloca na centralidade de seus enredos aqueles homens e mulheres que construíram suas vidas e histórias tecendo, dia a dia, com suas agências sociais os rumos coletivos. Respondendo ao historiador José Carlos Reis em entrevista, o próprio José Saramago esclarece:

[...] É essa a minha preocupação com as tais vidas que não deixaram sinal, que neste caso foram as vidas que puseram de pé o Convento de Mafra ou as pirâmides do Egipto ou o Aqueduto das Águas Livres. E não são só esses que fizeram os grandes monumentos e os tornaram visíveis: também há o trabalho comum das pessoas que, pela sua própria natureza, não deixaram sinais; porque pelo menos os carpinteiros e os pedreiros de Mafra deixaram materialmente algo. Mas há outros que não: os encarregados das obras que tomavam nota do número de telhas que entravam e das que eram usadas, esses provavelmente não deixaram nada, quando muito terão deixado a sua caligrafia em documentos que andam por aí. Ora, é essa necessidade de pôr no primeiro plano aqueles que aparentemente nada fizeram para lá chegar, que me leva (que me levou), por exemplo, a essa enumeração de nomes de operários no Memorial do Convento, que vai de $\mathrm{A}$ a $\mathrm{Z}$, como se cada um deles representasse todos os nomes começados por aquela letra (e cá estou eu a falar de Todos os Nomes, que é o título do romance que agora estou a escrever...). Ou seja: as pessoas todas que pudessem deixar as marcas. Porque a verdade é esta: quando encontramos um sinal da passagem dos primeiros seres humanos nesta terra, ficamos encantados. Entramos nas grutas de 
Altamira, por exemplo, e ficamos encantados; e não nos apercebemos de que, depois das grutas de Altamira ou de Lascaux e até hoje, passaram e continuam a passar muitos milhões de pessoas, que só tiveram o azar de não saber desenhar ou pintar, para deixar numa caverna qualquer um bisonte ou qualquer coisa no género (SARAMAGO, 2008, p. 60-61).

Sua empatia pelos esquecidos ou por aqueles que de alguma maneira não puderam deixar registrados sua passagem pela terra marcam seus romances.

Retomando a questão levantada acima, sobre o quem da pesquisa, é patente que a esta altura do enredo se processou uma mudança quanto ao lugar sociocultural das pessoas de quem o Sr. José pretendia conhecer a vida e a história. Na mesma direção, o que se coloca nesse momento como questão autorreflexiva no romance é uma questão de procedimento metodológico que remete diretamente ao problema da adequação da metodologia ao objeto investigado. No caso, ao procurar encontrar mais informações sobre a "mulher desconhecida", logo o Sr. José compreende os limites do arquivo, pois sobre ela as informações registradas se resumiam aos dados básicos: nome, filiação, idade, escola, nome do (ex) marido e endereço residencial.

Ou seja, para conhecer a história da "mulher desconhecida" o Sr. José deveria sair da conservatória geral "olhar o horizonte" e "embarcar [na] descoberta da ilha misteriosa" (SARAMAGO, 2014, p.48). Sua trajetória fora das paredes da conservatória geral o conduz, de fato, a novas descobertas. A primeira ideia do nosso auxiliar de escrita foi dirigir ao endereço registrado no verbete, pois era mesmo possível que ela ainda residisse no local. Assim, chegando ao prédio procurou o apartamento indicado, mas encontrou outra família vivendo no endereço e que não conhecia a antiga moradora. Já não se tratava de recolher informações nas paredes seguras do arquivo, mas de tatear no desconhecido, arriscarse em caminhos sem saída, tomar atalhos. Depois do limiar surgiam à frente do Sr. José múltiplos labirintos.

\section{Todos os nomes, todos os labirintos}

O Sr. José intuía que naquele prédio se encontrava "a ponta do seu fio de Ariadne" e por isso resolver seguir a indicação de que a moradora mais antiga do lugar talvez conhecesse a "mulher desconhecida" (SARAMAGO, 2014 , p.52). Chegando novamente ao prédio ele bate à porta da "senhora do rés-do-chão". Nesse momento, vê-se que houve um deslocamento significativo na abordagem do auxiliar de escrita, ele não estava mais trabalhando com verbetes, suas fontes agora eram pessoas. Nesse sentido, pensando em termos de procedimento metodológico, a mudança das personagens investigadas daria lugar, na pesquisa realizada, a uma nova abordagem.

Do arquivo para vida, essa mudança de direção na investigação desvela no universo de sentidos do romance novas possibilidades. A conversa que manteve com a senhora do rés do chão nos dá uma ideia de todo esse processo.

A mulher conduziu-o a uma pequena sala cuidadosamente arrumada e limpa, decorada com um gosto de outra época. Ofereceu-lhe uma cadeira, sentou-se, também e sem dar tempo ao visitante [sr. José] para novas perguntas disse, Fui sua madrinha de nascimento. O senhor José esperaria todas revelações menos esta. Tinha ido ali como simples funcionário que cumpre ordens dos seus superiores, portanto sem quaisquer envolvimentos de natureza pessoal, assim era necessário que o visse a mulher que estava sentada na sua frente, mas só ele sabe o esforço que teve para não se por a sorrir de beatífico deleite. E o seu marido foi padrinho, Sim. Poderei também falar com ele, Sou viúva, [...] A mulher disse, Dávamo-nos bem, quer dizer, as duas famílias, a nossa e a deles, éramos muito amigos [...] Que idade tinha a menina quando se mudaram, Creio que ia nos oito anos [...] Recebi uma carta pouco tempo depois [...] era uma carta que uma criança que não tem mais de oito anos, com as poucas palavras que sabe, é capaz de escrever à madrinha. $\mathrm{E}$ os pais, não lhe escreveram nunca, Não, Não achou estranho, Não, Porquê, São assuntos íntimos não são para devassar [...] Que assuntos íntimos foram esses. A mulher passou a mão pela testa, deixou cair lentamente as pálpebras murchas, depois disse sem abrir os olhos. A mãe da menina suspeitou que eu mantinha uma relação íntima com o marido, E era verdade, Era, desde a muito tempo, Foi por isso que eles se mudaram, Sim. A mulher abriu os olhos e perguntou agradam-lhe meus segredos [...] (SARAMAGO, 2014, p. 60).

Este foi o primeiro labirinto que o Sr. José teve que percorrer, porém já não se tratava da autenticidade e da legitimidade das informações de um verbete, mas de aproximação e contato. A "mulher do rés-do-chão", madrinha da "mulher desconhecida" expõe o auxiliar de escrita a laços afetivos, decepções e tristezas que mobilizam sensibilidades, antes de oferecer vestígios. Acerquemo-nos das noções de labirinto múltiplo, constituído por dobras; de labirinto do contínuo, o que pressupõe as redobras da matéria; e do labirinto da liberdade e suas dobras na alma, de Leibniz, e retomados por Deleuze. Tais espaços labirínticos, como em Leibniz, apesar de aparentemente distintos, constituem um continum, no dizer de Deleuze: "como um tecido ou folha de papel que se divide em dobras até o infinito" e que só é possível percorrer com o auxílio do fio de Ariadne (DELEUZE, 2005, p. 18). 
A conversa com a senhora do rés-do-chão vai da impessoalidade à confissão de segredos íntimos antes mesmo que o Sr. José consiga saber algo que de fato o ajude em sua investigação. O caminho labiríntico a que essa conversa conduz cria dobras nas quais Saramago compõe o jogo de linguagem que poderia ser tomado por historiadores como um exercício prático em história oral. A "senhora do rés-do-chão", assumindo uma postura dominante no diálogo, responde rapidamente à pergunta sobre se conhecia a "mulher desconhecida" na tentativa de impedir que o auxiliar de escrita fizesse novas perguntas, desviando-o de seus segredos íntimos.

Entretanto o Sr. José intercepta-a, conduzindo-a a falar sobre o tempo em que as famílias eram amigas. Aqui o campo já não é o da racionalidade, mas o da volatilidade dos afetos e seu impacto sobre as pessoas. Tomados, ambos, por momento de profundidade, passam a falar sobre felicidade, companheirismo e perdão, antes de uma chávena de café que tomaram quase em silêncio. Quando o Sr. José já quase dava por perdida aquela tarde, a senhora do "rés-do-chão" contou-lhe o endereço da escola onde a menina estudava quando criança. Ao deixar a casa da senhora Sr. José já havia se decidido a percorrer o próximo labirinto: iria à escola.

Aguardando chegar o fim da semana, o auxiliar de escrita seguia ansioso pela aventura que o aguardava. $\mathrm{Na}$ noite proposta saiu de casa depois da meia noite, pois o que faria não fazia parte dos procedimentos comuns de uma investigação: invadiria a escola. Protegido pela forte chuva, Sr. José esgueira-se e entra na escola depois de quebrar uma janela. Nesse estágio de sua investigação ele já se encontrava mais amadurecido e seguro quantos aos passos a seguir em cada labirinto. Assim, dentro da escola, e a despeito da dificuldade para atravessar a janela, o auxiliar de escrita agia:

[...] como um jogador de xadrez experiente, havia calculado todos os lances, na verdade não é tão difícil, quando se está seguro das causas objetivas imediatas, avançar prospectivamente pelo leque dos efeitos prováveis e possíveis e da sua transformação em causas, tudo a gerar em sucessão efeitos causas efeitos causas, até o infinito, mas sabemos que o Sr. José não será para ir tão longe (SARAMAGO, 2014, p. 94).

Embora não tendo a coragem de seguir rumo ao infinito ele planejou sua investida cuidadosamente: resolveu ir à escola em um fim de semana à noite; certificou-se de que não havia guardas e esperou que a sorte o ajudasse. Como deveria fazer um historiador, Sr. José buscava seguir um roteiro previamente definido, porém o acaso insistia em desviar-lhe de seus objetivos. Esse novo labirinto, assim como a Conservatória, estava plasmado em uma "escuridão [...] espessa" e, mais uma vez, o Sr. José precisaria tatear em um ambiente que parecia estar "envolvido em panos negros" na tentativa de descobrir a "mulher desconhecida" (SARAMAGO, 2014, p.97). Utilizando "seu eficaz mecanismo dedutivo", o auxiliar de escrita abandonou a sala escura onde estão guardadas as informações dos professores e alunos ativos e foi em busca dos arquivos dos antigos alunos, porém não os encontrava em nenhum lugar (SARAMAGO, 2014, p. 104).

Esgotado, ele ainda persiste, pois "depois de anos de Conservatória Geral [...] adquiriu um conhecimento de noite, sombra, escuro e treva que [...] que agora the permitia $[. .$.$] estender o braço por dentro do corpo do$ dragão à procura do interruptor da eletricidade", porém este não funcionou (SARAMAGO, 2014, p. 107-108). Ainda na espessa escuridão, o Sr. José conseguiu encontrar o arquivo morto da escola, o que o faz recorda imediatamente dos arquivos dos mortos da Conservatória, mas ali a luz acendeu.

Nesse momento do romance o contraste entre o escuro e o claro é que constrói a atmosfera da cena que remete à prática de pesquisa. $\mathrm{O}$ escuro permanente nos arquivos consultados pelo Sr. José figura, de um lado, a dificuldade para acessar as fontes e, de outro, a persistência com a qual segue tateando a vidas e a história da "mulher desconhecida" a cada dobra do labirinto. Porém, quando consegue acender uma lâmpada, a luz, mesmo opaca, lhe permite entrever vestígios do que tanto busca: naquele momento, quando o arquivo morto da escola se ilumina é que ele consegue encontrar a ficha escolar da "mulher desconhecida".

Essa aventura do Sr. José rendeu-lhe vários dias de um forte resfriado, quando se recuperou restou ir ao último endereço que constava no registro escolar, porém, ao contrário de bater à porta da casa, ele se pós a perguntar na vizinhança se alguém conhecia a "mulher desconhecida". A cada pessoa com quem conversava Sr. José exercitava sua retórica criativa ao ponto "assistir com prazer, quase com entusiasmo, ao exercício de capacidades inventivas que nunca imaginara ter" (SARAMAGO, 2014, p. 153). Nessa etapa de sua investigação nos parece que o auxiliar de escrita passa a compreender que para descobrir mais sobre a "mulher desconhecida" seria necessário que ele alçasse mão dos artifícios imaginativos, inventado uma proximidade com a referida mulher que jamais existira.

Além disso, parece que o narrador do romance tem a pretensão de ajudar o leitor a perceber o processo de transformação pelo qual o Sr. José passara desde que iniciara sua aventura investigativa. $\mathrm{O}$ empenho em conhecer mais sobre a "mulher desconhecida" o levara não apenas à busca em arquivos, mas ao contato humano e, ultimamente, a forjar uma capacidade criadora e 
imaginativa. Trata-se, certamente, do encaminhamento de uma pesquisa histórica.

Decidido a voltar, outro dia, à última casa conhecida da "mulher desconhecida", o Sr. José volta ao trabalho na Conservatória Geral, mas, em seu retorno, sofre um novo e contundente revês. Dentre suas tarefas daquele dia está um verbete em especial:

Agora está a puxar para si a décima sétima, prepara o verbete, e a mão treme-lhe, os olhos vacilam, a pele da testa cobre-se de suor. O nome que tem à sua frente, de um indivíduo do sexo feminino, é, em quase tudo, idêntico ao da mulher desconhecida, só no último apelido é que existe uma diferença, e, ainda assim, a primeira letra dele é a mesma. [...], levantou-se da cadeira mal acabou de fazer a transcrição, correu à gaveta respectiva do ficheiro, foi passando os dedos nervosos por cima das fichas, buscou, achou o lugar. $\mathrm{O}$ verbete da mulher desconhecida não estava lá. A palavra fatal relampejou imediatamente dentro da cabeça do Sr. José, a fulminante palavra, Morreu. [...] a mulher desconhecida estava morta (SARAMAGO, 2014, p. 162-163).

A mulher desconhecida morrera, ou seja, não estava na dinâmica dos arquivos dos vivos da Conservatória e isso deixou o Sr. José perplexo, pois não sabia como lidar com essa nova situação. Afinal, o arquivo dos mortos era um lugar aonde se ia raramente e o interesse por ele não era algo sobre o que o auxiliar de escrita já houvesse pensado.

\section{Todos os nomes, todas as histórias, todas as ficções}

Após saber da morte da "mulher desconhecida" e mesmo temendo o que encontraria, na mesma noite o $\mathrm{Sr}$. José foi ao arquivo dos mortos:

\begin{abstract}
Nessa mesma noite o Sr. José voltou à Conservatória. Levava consigo a lanterna de bolso e um rolo de cem metros de cordel forte. A lanterna continha uma pilha nova [...] Na falta do autêntico fio de Ariadne [...] O Sr. José servir-se-á de um rústico e vulgar rolo de cordel [...] e que reconduzirá ao mundo dos vivos aquele que, nesse momento, se prepara para entrar no reino dos mortos (SARAMAGO, 2014, p. 165).
\end{abstract}

Sua primeira incursão ao arquivo dos mortos possui significados e signos vinculados à pesquisa histórica. Primeiro, porque sua entrada no "reino dos mortos" representava, definitivamente, que sua pesquisa já não fazia parte do presente vivo e dinâmico, mas de um passado, ainda que recente, onde estariam guardados os segredos daquela que já não vivia: a "mulher desconhecida". Segundo, sua ida ao arquivo dos mortos, sustentado por um fio de Ariadne pressupunha seu retorno ao reino dos vivos e quem sabe o que ele traria de lá. Outra vez ele entra na escuridão dos arquivos, pois a "Conservatória está toda às escuras, mergulhada em densas trevas", aventurando-se "sozinho, no meio duma negra noite, por estas catacumbas de humanidade adentro, cercado de nomes, ouvindo o sussurrar dos papéis, ou um murmúrio de vozes, quem os poderá distinguir" (SARAMAGO, 2014, p. 168-169).

Seu objetivo era encontrar em algum ficheiro do arquivo dos mortos o verbete da "mulher desconhecida" e, assim, superando a escuridão, as teias de aranhas e o medo, o Sr. José nos guia por reflexão sobre a própria construção metafórica do romance e, consequentemente, sobre um caminho de pesquisa:

\begin{abstract}
Com método, sem precipitações, parecendo até que estava a recordar os gestos e os movimentos da noite que passou no sótão do colégio, quando a mulher desconhecida provavelmente ainda estava viva, o $\mathrm{Sr}$. José deu começo à busca. [...] No caso de não vir a descobrir nos níveis inferiores o que procura, o Sr. José terá de sacrificar-se novamente a subir uma escada de mão [...] está reiterada examinação das situações que vêm surgindo, estas aturadas reflexões, estas ponderações minuciosas sobre o claro e o escuro, sobre o direto e labiríntico, sobre o limpo e o sujo, estão a passar pela cabeça do Sr. José. O tempo empregado a explicá-las, ou, falando com rigor, a reproduzi-las, aparentemente exagerado, é consequência inevitável, não só da complexidade, tanto de fundo quanto de forma, dos fatores mencionados, mas também de natureza muito especial dos circuitos mentais do nosso auxiliar de escrita (SARAMAGO, 2014, p. 174).
\end{abstract}

A ida do Sr. José ao arquivo dos mortos é, de certa forma, uma retrospectiva de seu percurso até ali na busca da "mulher desconhecida". Uma espécie de cartase, onde ele começa, de um lado, a reconhecer o continum entre morte/vida/morte, ou seja, entre passado/presente/passado e, de outro lado, a perceber que deveria voltar a sua busca para outra direção, visto que não poderia encontrar a "mulher desconhecida" em sua existência material. Do ponto de vista da reflexão proposta pelo narrador esta, antes de dizer sobre o que pensava o Sr. José, que não era dado a grande meditação, é uma expressão da consciência de Saramago acerca da construção do romance, e subjacentemente, acerca do fazer literário.

A complexidade "tanto de forma quanto de fundo" à qual o narrador remete ao declarar a natureza, pouco explícita até o momento, das estruturas mentais do Sr. José, dizem mais sobre o fundo existencial e a forma literária do romance Todos os nomes, do que sobre a psicologia do personagem. Sobre o fundo falaremos mais à frente. Sobre a forma, esta se articula ao próprio estilo literário 
de Saramago, o qual se apresenta como metaficção ao revelar propositadamente os artifícios de sua produção literária e, de certa forma, provocar os historiadores a explicitarem também sua metodologia.

Quanto ao Sr. José, ele retornou ao mundo dos vivos com o verbete onde havia o assentamento da "mulher desconhecida" e, momentaneamente, estava convencido de que sua aventura terminara. É o que confidencia à "senhora do rés-do-chão":

Não se pode fazer mais nada, isto foi o que eu disse nesta altura, julgando que dava o assunto por encerrado, mas ela perguntou-me, Por que não vai falar com os pais, com o antigo marido, Para quê, Para saber alguma coisa mais a respeito da vida dela, como vivia, o que fazia (SARAMAGO, 2014, p. 198).

Sr. José ainda não admitia que houvesse qualquer serventia em conhecer a história da "mulher desconhecida" agora que estava morta. Contudo, a sugestão da "senhora do rés-do-chão" de que deveria procurar os pais da referida mulher lhe inquietava. Inquietava-lhe também ter confessado à "senhora do rés-do-chão" que mantinha um caderno de apontamentos sobre sua pesquisa que mais parecia um exercício no qual a imaginação procurava corrigir a história, como disse o próprio Saramago sobre o conjunto de sua obra. Seu caderno era:

Fiel no sentido, mas não tanto na forma, o que se compreende e desculpa, já que a memória, que é suscetível e não gosta de ser apanhada em falta, tende a preencher os esquecimentos com criações da realidade próprias, obviamente espúrias, mas mais ou menos contíguas aos fatos de cujo acontecer só lhe havia ficado uma lembrança vaga, como o que resta da passagem de uma sombra. Parecia ao Sr. José que ainda não tinha chegado a uma conclusão lógica do que sucedera. [...] Desesperava-se o Sr. José de entrar no sono quando de repente lhe surgiu, sabe-se lá de que profundidades, como a ponta de um novo fio de Ariadne, ansiada resolução, No sábado vou ao cemitério, disse em voz alta (SARAMAGO, 2014, p. 201).

Alguns aspectos merecem ser destacados aqui. Primeiro, o fato do Sr. José ter um caderno de campo converge para a ideia de que esse personagem não queria apenas conhecer a "mulher desconhecida, ele desejava, assim como Saramago em todo a sua obra" inscrevê-la em uma humanidade por meio do registro de sua existência. Segundo, o fato de que Saramago, em um movimento inverso ao da metaficção, expressa sua convicção em uma meta-história que revelaria em seus procedimentos que os fatos históricos são também criação. Discorrendo sobre a relação entre ficção e história no trabalho da historiadora norte-americana Natalie
Zemon Davis, o historiador Italiano Carlo Ginzburg escreve:

[...] situações análogas contribuem para preencher de certo modo as lacunas do caso que Davis se propôs a reconstruir. 'Quando não encontrava o homem ou a mulher que estava procurando, eu me voltava, medida do possível, para outras fontes do mesmo tempo e do mesmo lugar, a fim de descobrir o mundo que eles deviam conhecer e as reações que podem ter tido. Se o que ofereço é, em parte, de minha invenção, está, no entanto, solidamente arraigado nas vozes do passado' ( $\mathrm{p}$. 6-7). O termo invenção (invention) é voluntariamente provocatório - mas, no fim das contas, desviante. A pesquisa (e a narração) de Davis não é centrada na contraposição entre 'verdadeiro' e 'inventado', mas na integração, sempre escrupulosamente assinalada, de realidades e possibilidades (GINZBURG, 2007, p. 315).

O excerto citado por Ginzburg nesse trecho faz referência ao trabalho O Retorno de Martin Guerre (1987) escrito por Davis. Nessa obra a produção da narrativa tem como principal questão metodológica a relação entre história e ficção. A autora, na impossibilidade de preencher as lacunas do processo que estava investigando, recorre às fontes literárias e por meio delas cria cenários possíveis ou verossímeis. Talvez Ginzburg, marcadamente escrupuloso, restrinja muito a presença da invenção na narrativa histórica, porém ele e Saramago estão de acordo no que se refere à necessidade de integração entre realidades/fatos e criações/possibilidades, pois é desta articulação que é feita a história.

Terceiro, a percepção de que o Sr. José compreendeu que os mortos também interessam, pois são história e humanidade, o que é resolvido por meio de uma evidência metafórica: a ida ao cemitério. O cemitério é o último dos labirintos que o Sr. José percorre da "mulher desconhecida", porém ele é diferente de todos os outros labirintos, pois nele o que há escapa à vida, mas escapa à reinvenção da história. $\mathrm{O}$ Sr. José descreve o Cemitério Geral como um prédio cuja fachada é idêntica à da Conservatória Geral de certa forma tão labiríntico quanto com os "setenta e quatro tentáculos do polvo, que nunca lograria alcançar se não levassem um guia" (SARAMAGO, 2014, p.217).

Contudo, mesmo que tenha sido impossível usar um fio de Ariadne para se locomover no Cemitério, este parecia mais aberto às possibilidades de pesquisa que a Conservatória, com todos os seus métodos arquivísticos. Por outro lado, ali as pessoas se perdiam tanto quanto na Conservatória. Os reinos dos vivos e dos mortos aparentam, desde já, terem mais coisas em comum do que imaginou inicialmente o Sr. José.

Mas também havia diferenças, enquanto a Conservatória Geral era o lugar da escuridão e das densas 
trevas, o Cemitério Geral alternava entre o claro e o escuro: o Sr. José experimentou das duas ambiências no cemitério. Quando chegou a cemitério ainda era dia e seus pensamentos o direcionam agora ao contraste:

Veio à lembrança sua aventura no colégio [...] as mil dificuldades que lhe travaram o passo, até descobrir e finalmente penetrar no sótão misterioso, enfrentando a escuridão ainda mais assustadora que a dos arquivos dos mortos. Quem a tanto foi capaz de atrever-se não tem o direito de desanimar perante o esforço duma caminhada, por mais longa que seja, mormente estando a fazê-la à luz fraca do claro do sol, que, como sabemos, é amigo dos heróis (SARAMAGO, 2014, p. 229).

Aqui a luz se sobrepunha à escuridão não apenas porque era dia, mas também porque no jogo de contraste que a linguagem saramagiana propunha a estrutura labiríntica do cemitério não interpunha ao Sr. José uma dificuldade, mas uma impossibilidade. De fato, "quando ele chegou ao departamento dos suicidas, já com o céu peneirando as cinzas ainda brancas dos crepúsculos, pensou que havia se enganado de orientação ou que mapa estava mal desenhado", mas nenhuma dessas hipóteses era verdadeira (SARAMAGO, 2014, p. 230). Porém, após andar mais um pouco, quando o luar já apontava, "o Sr. José encontrou o que procurava [...] Está aqui, disse" (SARAMAGO, 2014, p. 231). Naquela noite, tendo resolvido esperar o dia amanhecer no cemitério, o "Sr. José passou frio" enquanto crescia dentro de si a sensação de que, mesmo tendo encontrado o túmulo, sua "busca ainda não tivesse terminado". Talvez não (SARAMAGO, 2014, p. 233).

A mulher desconhecida estava morta, o Sr. José estava em frente ao seu túmulo, mas ainda assim lhe parecia que não existia uma ruptura, mas "apenas um ponto de passagem". Chegada a manhã, o Sr. José teve um encontro decisivo: estava em sua frente um pastor com suas ovelhas a pastar tranquilamente no gramado do cemitério. O homem lhe perguntou o que fazia ali e o Sr. José respondeu que viera "ver a campa duma pessoa amiga, [e tendo] sent[ado a descansar debaixo daquela oliveira, adormec[eu]" (SARAMAGO, 2014, p.238). Mais uma vez o pastor lhe inquire se havia encontrado a quem procurava e Sr. José responde que sim.

Não satisfeito, o pastor pergunta ao auxiliar de escrita se seu interesse era profissional, talvez fosse "arqueólogo, Não, Historiador, Também não, Crítico de arte, Nem pensar, Pesquisador Heráldico, Por favor," respondia o Sr. José. (SARAMAGO, 2014, p. 239). Nesse momento o pastor compreendeu que o desejo do auxiliar era "conhecer a verdade do talhão do suicida" (SARAMAGO, 2014, p. 239). E segue o desfecho em um diálogo complexo:
Que neste lugar nem tudo é o que parece [diz o pastor], É um cemitério, é o Cemitério geral. É um labirinto [diz o pastor] Os labirintos podem-se ver de fora. Nem todos, este pertence aos invisíveis [pastor], Não compreendo, Por exemplo, a pessoa que está aqui, disse o pastor tocando no montículo de terra, não aquela que você julga (SARAMAGO, 2014, p. 239).

A ideia de que nem mesmo em um cemitério as coisas são o que parecem ser, aproxima de modo contundente o mundo dos vivos daquele dos mortos. O labirinto da Conservatória que se estenderia ao cemitério como um labirinto continum deleuziano integra, por meio da dificuldade de se compreender as relações para além das aparências, aqueles dois reinos diferentes, mas indissociáveis. A explicação de pastor acerca dos motivos pelos quais ele trocava os números dos túmulos é por demais simples para ser combatida: os suicidas abandonavam o mundo porque não queriam ser encontrados. A "mulher desconhecida" era uma suicida e como tal, mesmo antes de morta, parecia resistir, involuntariamente, de ser encontrada.

Aqui voltamos à questão de fundo proposta por José Saramago em Todos os nomes (2014). De fato, ainda que não quisesse ser encontrada, e mesmo depois de morta assim, o Sr. José encontrou a "mulher desconhecida". Não como um corpo no mundo, mas como uma história (re)construída no continum tempo que o registro permite. Para o historiador que deseja aprender com a literatura sobre metodologia, cremos que o caminho aberto em Todos os nomes (2014) nos levará a atar "uma ponta do fio de Ariadne ao tornozelo, avançar para escuridão" e rasgar os registros que condenam as pessoas à morte por meio do esquecimento, com sugeriu o conservador geral que o Sr. José fizesse.

\section{Referências}

CARR, Edward Hallet. O que é história? Tradução Lúcia Maria de Alverga. 4. ed. Rio de Janeiro, 1985.

DAVIS, Natalie Zemon. O Retorno de Martin Guerre. Tradução Denise Bottmann. Rio de Janeiro: Paz \& Terra, 1987.

DELEUZE, Gilles. A dobra: Leibniz e o barroco. Tradução Luiz L. B. Orlandi, 3. ed. São Paulo: Papirus, 2005.

FONTES, Maria Helena Sansão. O histórico e o ficcional na obra de José Saramago. E-scrita Revista do Curso de Letras da UNIABEU. Nilópolis, v. 1, n. 2, p. 75-85, maio/ago. 2010.

GINZBURG, Carlo. O Fio e os Rastros: verdadeiro, falso, fictício. Tradução Rosa Freire d'Aguiar e Eduardo Brandão. São Paulo: Companhia das Letras, 2007. https://doi. org/10.1590/s0104-87752009000100017 
REIS, Carlos. Diálogos com José Saramago. Lisboa: Editorial Caminho S.A., 1998. www.editorial-caminho.pt

SARAMAGO, José. A Historia como ficción, la ficción como historia. Debats, Madri, n. 27, p. 6-27, 1989.

SARAMAGO, José. Memorial do convento. São Paulo: Cia das Letras, 2013.

SARAMAGO, José. Todos os nomes. São Paulo: Cia das Letras, 2014.

Recebido em: 24/10/2018

Aprovado em: 22/01/2019.

Publicado em: 21/06/2019.

\section{Autores:}

Euclides Antunes de Medeiros

Doutor em História Social. Professor Adjunto do Curso de História da Universidade Federal do Tocantins (UFT) e do Programa de

Pós-graduação Interdisciplinar em Estudos de Cultura e Território

(PPGCULT-UFT), Campus da cidade de Araguaína-TO;

Coordenador do Grupo de Pesquisa História Regional: Memórias e

Territorialidades; Editor da Revista Escritas do Curso de História,

UFT/Araguaína; Membro do Núcleo Docente Estruturante-NDE.

Orcid: https://orcid.org/0000-0001-5200-5338

E-mail: eantunes@uft.edu.br

Olivia Macedo Miranda Cormineiro

Doutora em História Social. Professora Adjunta do Curso de História da Universidade Federal do Tocantins (UFT) e do Programa de Pós-graduação Interdisciplinar em Estudos de Cultura e Território (PPGCULT-UFT), Campus da cidade de Araguaína-TO;

Membro do Grupo de Pesquisa História Regional: Memórias e

Territorialidades; Editora da Revista Escritas do Curso de História, UFT/Araguaína.

Orcid: https://orcid.org/0000-0003-4297-1158

E-mail: oliviacormineiro@uft.edu.br

Endereço: Universidade Federal do Tocantins - Curso de História

Campus Universitário de Araguaína-TO

Rua Humberto de Campus, 508 - São João Batista

77800-000, Araguaina, TO, Brasil 